\title{
The Potential Taxation Of The Digital Sector In Indonesia That Comes From Digital Products From Abroad
}

\author{
Eka Prasetia Afandi, Elis Rismawati
}

Institut STIAMI

\author{
DOI: 10.29322/IJSRP.11.07.2021.p11571 \\ http://dx.doi.org/10.29322/IJSRP.11.07.2021.p11571
}

\begin{abstract}
This study aims to analyse the potential for taxation in the digital sector in Indonesia. As one of the countries with the most significant internet users, Indonesia makes many foreign companies interested in selling their digital content and services. The increasing number of foreign companies as developers and providers of digital content is in line with high technology in developed countries. Because of the enormous potential for taxation in this sector, the Government through Law No. 2 of 2020 in article 6 mentions tax treatment in trading activities through the electronic system, which is then regulated more clearly in the Regulation of the Minister of Finance Number 48/PMK.03/2020. This study uses qualitative methods using secondary data. Secondary data is in the form of other people's research, reviews, and summaries. In this study, the data taken is literature data that explain government policies to maximise the digital economy's tax potential. The results of this study explained that digital product transactions reached Rp102.67 trillion with a potential Value Added Tax (VAT) of Rp10.26 trillion. With this vast potential, and there will inevitably be an increase every year, the Indonesian Government in 2020 issued a tax policy for this digital product through Government regulation in place of Law No. 1 of 2020 and stipulated by Law no. 2 of 2020.
\end{abstract}

Index Terms- Taxes, Value Added Tax, VAT, Digital Economy, Digital Products, Revolution 4.0

\section{INTRODUCTION}

Currently, technology is developing rapidly every time due to globalisation and the industrial revolution 4.0. This 4.0 industrial revolution emerged from the digital revolution, which represented new ways to become embedded in society and even the human body (Purba and Yando, 2020:43). The development of technology has changed people worldwide. For example, the use of the internet in everyday life. Many of the daily activities of today's society depend on smartphones and internet connections. The growth in the number of devices in circulation and increasing internet users have made people's digital content consumption and services also increase, including in Indonesia. Through advances in technology and the internet, Indonesian people can access digital content or services from within the country and abroad, causing cross border transactions easily and quickly.

The development of digital content and services in Indonesia in line with the first entry of the internet. According to Purbo in Utomo (2017), the internet was used commercially for the first time in 1994 when IndoNet established the first commercial Internet Service Provider in Indonesia. This moment marks the start of the digital information era in Indonesia. Today, almost all information are available on the internet. The development of technology and innovation has made many new digital content products that we encounter today.

Since 2020, the world has been experiencing a pandemic, namely the Covid-19 virus, which has made many people unable to carry out their everyday activities. This pandemic also causes accelerated changes in people's behaviour, especially in buying/selling goods/services. Based on a report from Deloitte (2020) entitled "Covid-19 will permanently change e-commerce in Denmark", it is stated that the pandemic is rapidly changing our behaviour toward online channels. The shift is likely to stick post-pandemic, which indicates that in the future, there will be more transactions and activities carried out online even though this pandemic is over. This shift in community activities, especially in terms of buying/selling goods/services transactions, has created a new discussion regarding the potential for taxation in the digital transaction sector. This shift from traditional transactions to digital transactions creates challenges for policymakers in a country. These challenges require an evolution in taxation and create opportunities to expand the tax base in Indonesia.

As one of the countries with the most significant internet users and users of digital products globally, Indonesia makes many foreign companies interested in selling their digital products in the form of digital content or services. The number of foreign companies as developers and providers of digital products is in line with the high technology utilisation level in developed countries. The digital content or service itself can be in advertisements, videos, music, applications, and various other things. As quoted from Media Indonesia (May 17, 2020), Indonesia's potential revenue from the digital sector reaches IDR 15 trillion or a minimum of IDR 10 trillion through the concept of Income Tax and Value Added Tax. This statement confirmed by the OECD report in BEPS Action 1, which divides the problems in digital economy taxation into two parts. However, the concept of Income Tax in Indonesia blocked by the regulation of the foreign company becoming a BUT (Permanent Form of Business) or a permanent establishment in the country following the OECD Model Tax Convention Articles 5 and 7. The implementation of the Income Tax concept, the Government through Law No. 2 of 2020 in article 6 mentions tax treatment in trading activities through the electronic system, which is then regulated more clearly in the Regulation of the Minister of Finance Number 
ISSN 2250-3153

48/PMK.03/2020 concerning the collection procedure, depositing, and reporting VAT on the utilisation of intangible taxable goods and taxable services from outside the customs area within the customs area through trading through an electronic system.

\section{LITERATURE REVIEW}

Tax is one of the most significant revenues from a country compared to other sources of revenue. Through taxes, a country can fulfil its citizens' rights and taxes themselves are an obligation for every citizen. With the country's tax receipts, the country can prosper its citizens through infrastructure development, education services, health services, and various other things. Taxes, according to the Law on General Provisions of Taxation Law no. 28 of 2007, is a mandatory contribution to the state that individual or entity has to pay that is coercive based on the Law, with no direct compensation and used for the needs of the state for the greatest prosperity of the people. The development of the times leads to an evolution in taxation, one of which is the potential for tax revenue from the digital economy sector.

The concept of a digital economy is not new but has been around since the 1900s and introduced by Don Tapscott. According to Tapscott (1996), the digital economy or other terms of the new economy have characteristics that indicate the use of digital information exclusively, not only limited to the information technology market. Meanwhile, according to Hartman and Sifonis (2000), it is "the virtual arena in which business is actually created and exchanged, transactions occur, and one-to-one relationship matures by using any internet initiative as a medium of exchange". People can see this digital economy from the increasingly rapid development of business or trade transactions using internet media as a medium for communication, collaboration, and cooperation between companies and between individuals. Another definition of the digital economy (Deloitte, 2019) is an economic activity that results from billions of online connections of many people, businesses, devices, data, and processes. The backbone of this digital economy is hyperconnectivity, where there is an increasing connection between people, organisations, and machines due to the internet, mobile technology, and the internet of things (IoT). So that with the digital economy, it is possible to carry out trade transactions in goods or services through electronic commerce on the internet (OECD, 2012). The OECD in 2014 listed business revenue models in the digital economy, including income from advertising, sales or rental of digital content, sales of goods, revenue from subscription fees, sales of services, including traditional services provided digitally, revenue from content licensing. Furthermore, technology includes journals or publications, algorithms, software, revenue from selling user data and market research, and income from hidden costs and losses (Utamawati, Wijaya, 2020: 49).

Wijayanti (2020) says the digital tax is a tax imposed on companies that operate and have products in information technology. Companies engaged in this field are one of the potential sources of new taxation discussed by all countries. As a country that relies on taxes as a source of state revenue, Indonesia has several types of taxes, one of which is Value Added Tax or VAT. According to Sukardji (2015), VAT is a tax on the consumption of goods or services within the customs area by individuals or entities. Value Added Tax is also a tax levied on every value-added of a good or service delivered from the producer to the consumer (Pohan, 2016:22). Value Added Tax or VAT has two collection principles, including the principle of a place of origin and the principle of destination. The origin's principle means that taxes are imposed where goods are produced regardless of where goods are consumed. At the same time, the destination principle means taxes are imposed where goods are consumed regardless of where the goods are produced. These principles influence in determining tax collection policies in international trade where VAT is neutral. This neutral tax was put forward by John F. Due, which means that taxes do not affect people to choose an item to be consumed and do not affect producers who will do production, and do not make people not eager to work (Pohan, 2016:49-50).

According to the Law of the Republic of Indonesia Number 2 of 2020, regarding tax treatment on Trading activities through the Electronic System (PMSE). The Law explains an imposition of Value Added Tax on the utilisation of Intangible Taxable Goods and Taxable Services outside the Customs Area within the Customs Area through Trading Through the Electronic System (PMSE). Trading through the Electronic System is a trade whose transactions carried out through a series of devices from electronic procedures referring to Article 1 of the Government Regulation of the Republic of Indonesia Number 80 of 2019. The implementation mechanism regulated in the Regulation of the Minister of Finance of the Republic of Indonesia Number 48/PMK.03/2020 concerning procedures for appointing a tax collector, collection and deposit, as well as reporting of Value Added Tax on the utilisation of Intangible Taxable Goods and Taxable Services from outside the Customs Area within the Customs Area through Trading Through the Electronic System (PMSE) and Regulation of the DirectorGeneral of Taxes Number PER-12/2020 concerning Limitation of Certain Criteria for Collectors and Appointment of Collectors, Collections, and Deposits, as well as Value Added Tax Reporting on the utilisation of Intangible Taxable Goods and Taxable Services from outside the Customs Area within the Customs Area through Trading Through the Electronic System (PMSE).

\section{RESEARCH METHODOLOGY}

The research methodology used is qualitative. Raco (2013) states that qualitative research is a theoretical idea with techniques and procedures to reveal facts to obtain complete information. The source of the data taken is secondary data, which is not obtained directly from the data source (Sugiyono, 2018). Secondary data is in the form of other people's research, reviews, and summaries. In this study, the data taken is literature data that explain government policies to maximise the tax potential of digital products provided by foreign companies.

\section{RESULT AND DISCUSSION}

The development of the era that causes increasingly advanced technology causes many demands for changes made by the world community. Taxation is no exception, which must evolve with the times and people's behaviour. The current era of modern society will continue to develop into a digital society where technology will become something essentially all the time. The term digital economy appears, which has many implications in taxation. Advances in technology, both devices and the internet, and since the Covid-19 pandemic has accelerated the behaviour of people who still carry out conventional transactions into digital transactions. This digital transaction made the seller not have to meet directly with the 
ISSN 2250-3153

buyer to cross borders between countries. It triggered the increasing number of companies, especially overseas, to become providers of digital products in digital content or services. The term of service provided by this digital content or service provider is Over-The-Top (OTT) service.

HootSuite and We Are Social (Kompas, 2021) state; current data shows that internet users in Indonesia in early 2021 reached 202.6 million people. When compared with the population in Indonesia, which reached 274.9 people, the percentage of internet users in Indonesia reached 73.7 per cent. From this data, there are 195.3 million Indonesians who use smartphones to access the internet. The average internet user in Indonesia spends 8 hours 52 minutes divided into social media, watching videos or streaming, reading news, listening to music on streaming services, and listening to radio or podcasts. According to Digital (Kompas, 2021), almost all internet users in Indonesia, or around 98.5 per cent, watch online videos every month. This data can be used as a basis that the potential for transactions on digital products in Indonesia is enormous. Of course, it is also a potential for taxation. The magnitude of this potential makes many foreign companies compete to sell their digital products to Indonesia, both in digital content and services. Some examples of foreign companies selling their digital products to Indonesia include Google, Netflix, Spotify, Facebook, Twitter, et cetera.

The Government as a regulator, in previous years, has asked foreign content or service providers to build servers in Indonesia which in the future will open branch offices in Indonesia. However, for now, in Indonesia, no regulation requires it. Ketut (Bisnis, 2020) states that regulations for OverThe-Top service provider companies only exist in Government Regulation PP Number 71 of 2019 concerning Electronic System and Transaction Operations. The contents do not require private or private information commercial electronic system operators to build central data in Indonesia. So that digital product providers from abroad want to open branch offices or build servers in Indonesia, there needs to be a revision of these rules. With this regulation, the Government cannot arbitrarily collect income taxes from content or service providers from abroad.

According to data from the Taxation Omnibus Law academic text (Bisnis, 2020), in 2017, digital product transactions reached IDR 102.67 trillion with a potential Value Added Tax (VAT) of IDR 10.26 trillion. With this vast potential and there will inevitably be an increase every year, the Government of Indonesia in 2020 issued a tax policy for digital content or services through Government regulation in place of Law No. 1 of 2020 and stipulated by the Law of the Republic of Indonesia No. 2 of 2020. The previous regulation, namely Government Regulation Number 80 of 2019, explains Trading Through the Electronic System (PMSE). Directorate General of Taxes conducts press releases. The emergence of Law no. 2 of 2020 creates equal tax treatment between conventional business actors and digital economy business actors domestically and abroad. It provides legal certainty to collect Value Added Tax on the use of Intangible Taxable Goods. And Taxable Services from outside the Customs Area within the Customs Area through Trading Through the Electronic System (PMSE). The Law of the Republic of Indonesia Number 2 are Minister of Finance Regulation Number 48/PMK.03/2020 and are followed by other related regulations. In this regulation, Intangible Taxable Goods and Taxable Services from outside the customs area or what we are more familiar with digital content or services from abroad are subject to tax in the form of Value Added Tax (VAT) of 10 (ten) per cent of the tax base. The tax base in question is the value of money paid by the buyer, not including the value of Value Added Tax.

The imposition of VAT on digital product transactions from foreign providers adheres to the destination principle mean taxes are imposed where the digital product is consumed. This principle makes it easier for the Directorate General of Taxes to implement for foreign companies providing digital products, most of which are based abroad and do not have a branch office in Indonesia but make Indonesia one of the destination sources of income. This principle relates to the OECD (2014), which states that the Value Added Tax in transactions between countries uses the destination principle. The world has accepted this principle widely for its application in international trade. In its implementation in Indonesia, the Directorate-General of Taxes sets certain criteria for Trading Business Actors through Electronic Systems appointed as Value Added Tax collectors. Entrepreneurs of Trading Through Electronic Systems must meet the criteria; namely, the value of transactions with Goods Buyers and Service Recipients in Indonesia exceeds a certain amount in 12 (twelve) months. The amount of traffic or access exceeds a certain amount in 12 (twelve) months. Regulation of the Director-General of Taxes Number PER-12/2020 sets criteria, which states that the limit on the value of transactions with Buyers of Goods and Recipients of Services in Indonesia exceeds Rp. 600,000,000 (six hundred million Rupiah) in 1 (one) year or Rp. 50,000,000 (five hundred million Rupiah). Twenty million Rupiah) in 1 (one) month, and the amount of traffic or access in Indonesia exceeds 12,000 (twelve thousand) in 1 (year) or 1,000 (one thousand) in 1 (one) month.

The mechanism for collecting Value Added Tax on digital product transactions in Indonesia uses the principle of supplier collection where foreign tax subjects who do not have offices or companies in Indonesia become Value Added Tax collectors. According to the explanation in the Regulation of the Minister of Finance Number 48/PMK.03/2020 Article 2 (2) states that the Value Added Tax as referred to in paragraph (1) is collected, deposited, and reported by PMSE (Trade Through Electronic Systems) Business Actors. ) appointed by the Minister. At the same time, Article 2 (1) refers to the Value Added Tax imposed on the utilisation of Intangible Taxable Goods and Taxable Services outside the Customs Area within the Customs Area through Trading Through the Electronic System. So that companies providing digital products from abroad do not only sell to consumers in Indonesia but have other obligations as VAT collectors, depositors, and reports to the Indonesian tax authorities, namely the Directorate General of Taxes. According to Schenk and Oldman (2007), the tax subject of the supplier collection mechanism who comes from abroad and does not have an office in a country may be subject to the regulations in force in that country. Meanwhile, based on the OECD (2017), this supplier collection mechanism is an alternative that tax authorities in a country can take to collect taxes from digital content or service transactions from foreign providers. Quoted from Miftahudin and Irawan (2020), the idea of supplier collection has a history that emerged from conferences between countries related to increasingly borderless community interaction (borderless world), impacting the growth of technology and e-commerce transactions in the world.

The imposition of Value Added Tax for digital products in Indonesia originating from abroad began on July 1, 2020. The 
ISSN 2250-3153

appointment of such Value Added Tax collectors has so far been in eight waves with 57 business entities. Collection of Value Added Tax for digital product providers from abroad has not only implemented in Indonesia, but many countries have also implemented it. According to Yustinus in Wijayanti (2020), 29 countries are members of the OECD, such as India, South Africa, Russia, the European Union, and other countries that have implemented the mechanism for collecting Value Added Tax. Quoted from Click Tax (2020), countries in the European Union are getting value-added tax growth from digital taxes. For example, in 2015, the value of Value Added Tax obtained was EUR 3 billion, and in 2018, the value obtained increased to more than EUR 4.5 billion. Another example in Australia also reported a growth in taxes derived from the digital sector. The tax earned was AUD 728 million for the first two years, while the first target was AUD 348 million for the first year only. This data shows an increased tax revenue trend from the digital sector, which can be one of the significant sources of tax revenue in the future.

\section{CONCLUSION}

The digital economy has changed the way of transacting and the lifestyle of the world's people. The existence of these changes is certainly a challenge for policymakers, especially in terms of taxation. Of course, this challenge must be answered with an evolution in the taxation sector to align with existing developments. This case applies the Value Added Tax, which the Government of Indonesia applies to digital products provided by service providers originating from abroad. Taxation on digital products is currently the latest topic of discussion. All countries widely discuss it because of the great potential where technological advances make it easy for someone to purchase digital content or services. Of course, to maximise this potential in the taxation sector, the Indonesian Government must find currently limited solutions. As is well known, one of them is the application of Income Tax for companies that provide products from abroad. There is a change in Government Regulation PP Number 71 of 2019 concerning Electronic Systems and Transactions. Later, Over-The-Top service providers are required to create a data centre in Indonesia and take the form of a BUT so that the Government can apply Income Tax. However, before that, a more in-depth study of the application must be carried out to not conflict with the applicable domestic and international regulations.

The Government's initial step by issuing the Law of the Republic of Indonesia Number 2 of 2020 is appropriate because the withdrawal of Value Added Tax applies the destination principle and commonly used by many countries as a source of tax revenue from digital transactions. With the increasing potential for taxation in this field every year and in the future, of course, the competent authorities must always follow the existing trends in every policy setting regarding taxation in the digital sector. In the future, the Government, through the Directorate General of Taxes, must supervise the tax collection and reporting activities on these digital transactions and further expand the tax objects and tax subjects. Because as is known, developments in the world of technology are swift, and there are still many gaps that can be exploited for Over-The-Top companies from abroad to avoid the current tax system. In addition, there is a need for supporting regulations for violators of tax policies applied to trade transactions through this electronic system to create a high level of compliance from digital product providers from abroad.

\section{REFERENCES}

(1). Cahyadini \& Margana, (2018). Kebijakan Optimalisasi Pajak Penghasilan Dalam Kegiatan E-Commerce, VeJ Vol 5. No. 2.

(2). Miftahudin, Irawan, (2020). Alternatif Kebijakan Pajak Pertambahan Nilai Atas Konsumsi Atau Pemanfaatan Konten dan Jasa Digital Dari Penyedia Luar Negeri. Jurnal Kajian Ilmiah Perpajakan Indonesia, Vol 1. No. 2.

(3). Nyrop et al., (2020). Covid-19 will Permanently Change E-Commerce in Denmark, Deloitte.

(4). OECD, (2014). Addressing the Tax Challenges of the Digital Economy, Paris: OECD Publishing.

(5). OECD, (2015). Addressing the Tax Challenges of the Digital Economy, Action 1 -2015 Final Report. Paris: EOCD Publishing.

(6). OECD, (2017). Model Tax Convention on Income and Capital: Condensed Version 2017, Paris: OECD Publishing.

(7). OECD, (2017). International VAT/GST Guidelines, Paris: OECD Publishing.

(8). Pohan \& Anwar, (2016). Pedoman Lengkap Pajak Pertambahan Nilai. Jakarta: PT Gramedia Pustaka Utama.

(9). Purba, et al, (2020). Revolusi Industri 4.0. Batam: CV. Batam Publisher.

(10). Utomo, (2017). Tantangan Pengawasan PPN Atas Transaksi Konten Digital. Jurnal Pajak Indonesia Vol. 1, No. 1.

(11). Raco, (2010). Metode Penelitian Kualitatif: Jenis, Karakteristik, dan Keunggulannya. Jakarta: PT Grasindo.

Schenk \& Oldman, (2007). Value Added Tax: A Comparative Approach. Cambridge: Cambridge University Press

(12). Sugiyono, P., (2018). Metodologi Penelitian Mix Method. Bandung: Alpabeta.

(13). Sukardji, (2003). Pokok-Pokok Pajak Pertambahan Nilai Indonesia. Depok: Raja Grafindo Persada.

(14). Tapscott, (1996). The Digital Economy: Promise and Peril in the Age of Networked Intelligence. New York: McGraw-Hill.

(15). Wijaya \& Utamawati, (2018). Pajak Penghasilan dari Ekonomi Digital atau Cross-Boarder Transacation. Jurnal Online Insan Akuntan, Vol 3. No. 2.

(16). Wijayanti, (2020). Pajak Digital: Potensi dan Tantangan. Jurnal Optimum, Vol. 10, No. 1.

(17). Al Machmudi, M. Iqbal, (2020). "Potensi Pajak Digital Capai Rp15 Triliun", https://mediaindonesia.com/ekonomi/313805/potensi-pajakdigital-capai-rp15-triliun, diakses pada 15 April 2021 pukul 19.20.

(18). Hafidh, (2020). "Selain Indonesia, Ini Penerapan Pajak Digital Global di Negara Lain". https://klikpajak.id/blog/berita-regulasi/penerapanpajak-digital-global/, diakses pada 18 April 2021 pukul 12.00

(19). Jatmiko, Leo Dwi. 2020. "Terungkap! Ini Alasan Server Netflix Tidak Ada di Indonesia". https://teknologi.bisnis.com/read/20201012/101/1303810/terungkapini-alasan-server-netflix-tidak-ada-di-indonesia, diakses pada 17 April 2021 pukul 19.30

(20). Riyanto, (2021). "Jumlah Pengguna Internet Indonesia 2021 Tembus 202

https://tekno.kompas.com/read/2021/02/23/16100057/jumlahpengguna-internet-indonesia-2021-tembus-202-juta, diakses pada 17 April 2021 pukul 17.00

(21). Undang-Undang Republik Indonesia Nomor 28 Tahun 2007 tentang Ketentuan Umun dan Tata Cara Perpajakan.

(22). Undang-Undang Republik Indonesia Nomor 2 Tahun 2020 tentang Kebijakan Keuangan Negara dan Stabilitas Sistem Keuangan untuk Penanganan Pandemi Covid-19.

(23). Peraturan Pemerintah Nomor 80 Tahun 2019 tentang Perdagangan Melalui Sistem Elektronik.

(24). Peraturan Menteri Keuangan Nomor 48/PMK.03/2020 tentang Tata Cara Pemungutan, Penyetoran, dan Pelaporan PPN atas Pemanfaatan Barang Kena Pajak Tidak Berwujud dan/atau Jasa Kena Pajak dari Luar Daerah Pabean di Dalam Daerah Pabean Melalui Perdagangan Melalui Sistem Elektronik.

(25). Peraturan Dirjen Pajak Nomor PER-12/2020 tentang Batasan Kriteria Tertentu Pemungut Serta Penunjukan Pemungut, Pemungutan, dan Penyetoran, serta Pelaporan Pajak Pertambahan Nilai atas pemanfaatan barang Kena Pajak Tidak Berwujud dan/atau Jasa Kena Pajak dari luar Daerah Pabean di Dalam Daerah Pabean melalui Perdagangan Melalui Sistem Elektronik (PMSE).

\section{AUTHORS}

First Author - Eka Prasetia Afandi, S.E., M.M., CSCA, CSCM, CTLC, QWP®, Institut STIAMI, eka.afandi@gmail.com

Second Author - Elis Rismawati, Institut STIAMI, elis.rismawati@yahoo.com 